\title{
Three regius professors, sanitary science, and state medicine: the birth of an academic discipline
}

\author{
ROY M ACHESON
}

The bases of most subjects taught in the medical curriculum are plainly evident: anatomy is concerned with the structure of the body, psychiatry with the diagnosis and treatment of diseases of the mind, medical sociology with the influence of the structure and functioning of society on disease and medical practice, and so on. The teaching of each basic science derives from past and present research by those engaged in the subject, and in each clinical specialty it takes the form of an apprenticeship. All this was as true of teaching in the good medical schools in the sixth and seventh decades of the last century as it is now. But how, 115 years ago, did a subject called state medicine come into being in medical schools? I describe the means whereby sometime in the mid nineteenth century three regius professors - two of physic and one of medicine; two English and one Irish; inspired, among others, by a Welsh general practitioner from Cheltenham-persuaded the government and their universities to provide postgraduate education in public health and to monitor its standards. The Scots moved with them but followed their own route. But nowhere in the British Isles was there a cadre of established masters to whom the students could be apprenticed, nor was there a single established science on which teaching could be based.

It was not until 24 years later, in 1895, that uniformity and satisfactory standards began to be achieved; on 29 November of that year the General Medical Council for Medical Registration and Education accepted reports from its Inspector, Dr G F Duffey, on the examination in public health in 12 universities and colleges. By then 15 examining bodies offered certificates or diplomas in the subject. Gestation had been long, but just how long depends on when conception occurred. Some may judge this to have been when Chadwick's report on the Sanitary Condition of the Labouring Population of Great Britain was published in 1842 or when his great public health Act was passed in 1848, others when the first medical Act was passed 10 years later; but the strongest case can probably be made for the publication in 1856 of the visionary Henry Wyldbore Rumsey's Essays in State Medicine. ${ }^{1}$

That concern should grow about both the training and the remuneration of doctors practising state medicine was at any event a natural consequence of the passing of Chadwick's Act, and the GMC, which held its first meeting in the Royal College of Physicians in 1858 , provided a natural forum for the matter to be considered.

\section{Dramatis personae in the GMC}

The first GMC comprised 23 members; six were appointed by the Queen in council, including William Stokes from Ireland and Sir Robert Christison from Scotland-both of whom feature in this-and 17 were nominated by the Royal Colleges and the licensing bodies, as the recognised medical schools were (and still are) called at law. But the man present at that first meeting who was to contribute most to the satisfactory establishment of training in state medicine and public health was Sir Henry Acland, regius professor of medicine in (and nominated by) the University of Oxford (fig 1). Stokes and Acland were joined in 1863 by George Paget, who represented the University of Cambridge, where he was Linacre lecturer, and by Rumsey, who was a Queen's appointment. A theological simile may be regarded as in bad taste, but it is difficult to resist looking upon Rumsey, the

Department of Community Medicine, University of Cambridge, Level 5, Addenbrooke's Hospital, Cambridge CB2 2QQ

ROY M ACHESON, FRCP, FFCM, professor of community medicine charismatic master of words, as John the Baptist, who heralded a powerful triumvirate (if not a Trinity); the triumvirate comprised the medical regius professors in Oxford, Cambridge, and Dublin. Paget became president of the GMC in 1869 and served until 1874 , when he resigned on his election to the regius chair in his university. He was succeeded in the presidency by Acland, who held the post for 15 years until the foundation had been laid for postgraduate education in what had been state medicine (but was becoming public health) to become established at a satisfactory standard throughout Britain and Ireland.

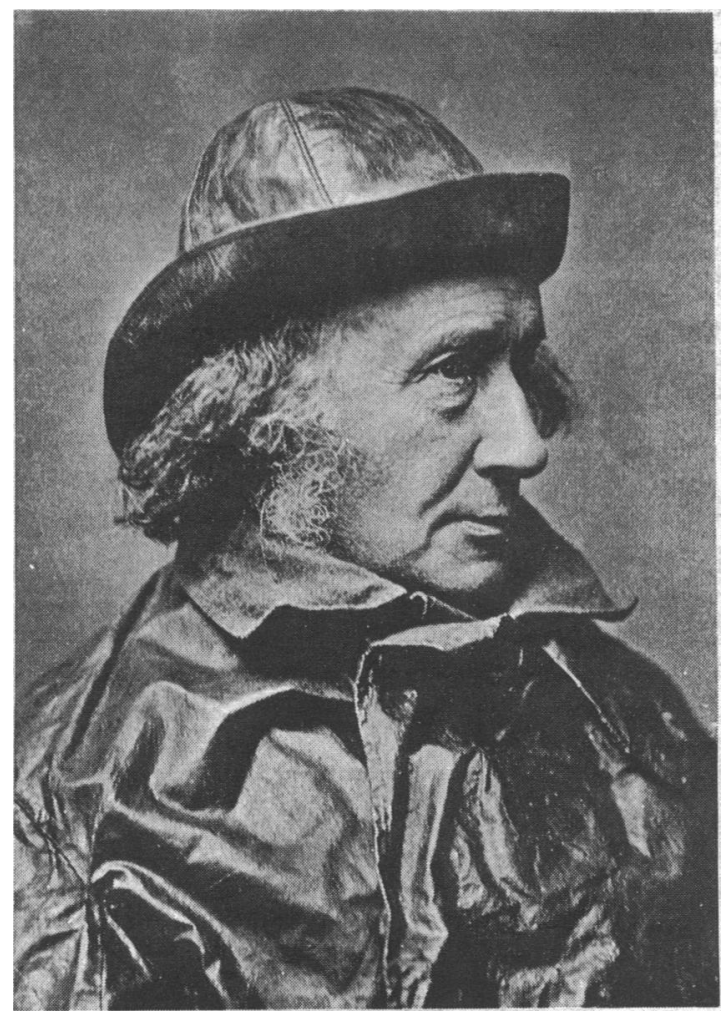

FIG 1-Sir Henry Acland Bt (1815-1901), who was a keen sailor, in his oilskins in 1880 . Among his many achievements were the establishment of science and modern medicine in Oxford.

The first indication of an interest in state medicine among the three was a statement by Paget in his presidential address to the British Medical Association at the annual meeting held in Cambridge in 1864 that "a comprehensive knowledge of sanitary science should be employ(ed) ... in the public service." Acland was there to hear him, and there as well as at the meetings of the GMC the two of them together with Stokes and Rumsey would have had the opportunity to lay plans to implement the ideas set out in Essays in State Medicine.

\section{Rumsey's concept of state medicine}

State medicine was an amorphous concept; in England it seems to have emerged from the realisation that there was much to be done in the maintenance and promotion of health which could be done only by "medical men," but who could not reasonably be expected to carry out this work effectively and at the same time support themselves with clinical fees paid by patients. It connotated a heterogeneous range of tasks directed towards 
populations. Some of these had been written by Chadwick into the Act of 1848 , some had not but were of benefit to the public; tacit also was the concept of a salary from public funds. The name appears to have been coined by Rumsey (fig 2), who pointed out in his book in 1856 that it was a simple translation of the German Staats-arnzneikunde. Nevertheless, the responsi-

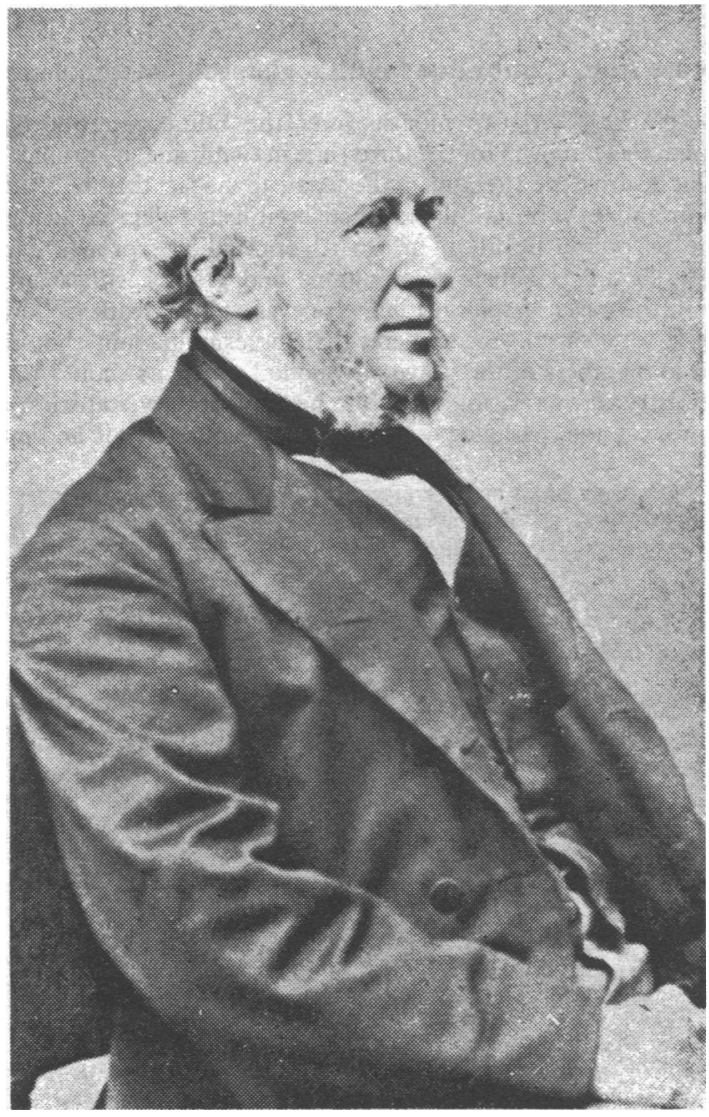

FIG 2-Henry Wyldbore Rumsey, (1809-76), physician and writer, who poured his substance into the promotion of state medicine. He presented at his own expense 100 copies of his book Essays in State Medicine to the Epidemiological Society so that every member had one. On his death a successful national appeal was launched to support his family. (Courtesy of the librarian of the Wellcome Institute.)

bilities that he set out far exceeded those discharged by the Kreisphysikus or Districtartz, both of whom had to depend heavily on fees from private medicine. Among other things, the English state physician should be responsible for the investigation of epidemics, medical care of the poor, registration of vital events, health of factory workers, and local sanitary administration. In Rumsey's view the last of these included providing reliable scientifically based medical evidence for forensic inquiries, including conducting postmortem examinations; surveillance and control of adulteration of food, drinks, and medicines; vaccination against smallpox; inspection of hospitals and asylums; and accepting responsibility for the quality of medical evidence in court. He recognised that if any such service supported by the state was to be provided the country would have to be partitioned topographically into manageable areas. Clearly, if his vision was to be realised each state physician would have to be a polymath.

\section{BMA goes to Dublin and work begins}

In 1867 , three years after the Cambridge meeting, the BMA went for the first time to Ireland, where in Trinity College Dublin the meetings seem to have been a considerable scientific and social success. It is clear that the scenario had been carefully prepared and the actors well rehearsed. Stokes (fig 3 ) in his inaugural presidential address chose to introduce the principal speakers and their subjects: Rumsey and his proposals for state medicine received top billing and Stokes spoke at length of the importance of Rumsey's work and of the need to introduce a certificate or diploma of competence in state medicine. Rumsey's brief, detailed, and flowery paper was enthusiastically received, and during ensuing discussions the association resolved that its council should pay special attention to the amendment of the sanitary laws; it directed further that the cooperation and support of the National Association for the Promotion of Social Science might be sought. A BMA state medicine committee was formed with Acland as its chairman and Rumsey among the members. One of its first actions was to write to the GMC and propose that it too should form a state medicine committee. The council complied in June 1868, Acland again being elected chairman; Paget and Stokes were members, as were Rumsey, Edward Parkes (the great military hygienist), and Sir Robert Christison. A year later the GMC committee reported to the council that "there was no sufficient guarantee for the general competency, or the special qualification of medical men appointed to the post of medical officer of health ... no recognised plan for conducting their education nor any examining body for regulating the standard...." The response of the council was immediate and positive, as we shall see below, but the constraints within which those who wanted to shift officialdom had to work made permanent change pathetically slow.

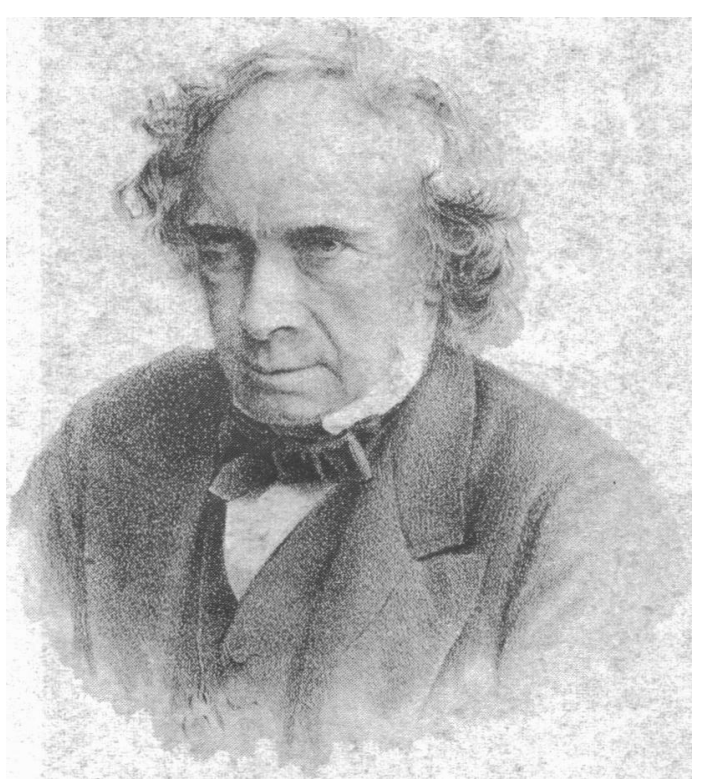

FIG 3-William Stokes (1804-78), distinguished exponent of the stethoscope, who with his father, Colles, Cheyne, Corrigan, and Graves among others formed the Irish School of Medicine. (Courtesy of the provost and fellows of Trinity College Dublin.)

\section{Separate qualifications for graduates in Dublin and Cambridge}

Action was more rapid behind the scenes. In May 1868 Paget (fig 4) had with brilliant foresight persuaded Cambridge University to accept state medicine as one of four suitable subjects for the MD degree; the others were practical medicine, pathology, and physiology. This rule was implemented in 1870. The MD is still one of the most senior degrees there, but at that time it did not have to compete for prestige with the $\mathrm{ScD}$ or the PhD. Moreover, it was available only to graduate members of the university. On 28 January 1870 the medical questions syndicate took a further step by drawing the attention of the senate in Cambridge to a need to find means for testing the fitness of people filling "the recently created offices in preventive medicine" and for certifying this test. The very next week in Dublin Stokes, who had raised the matter with his professorial committee two months previously, laid before his committee the Cambridge documents of May 1868 and January 1870 , which he had received under cover of a personal letter from Paget. The medical professors formally recommended to the Board of Trinity College (the governing body of the university) that a qualification in state medicine should be instituted. In his letter to the board Stokes referred to the "steps taken in Cambridge," by which he meant the MD and proposed certificate, and went on to set out the peculiar advantages possessed by the University of Dublin for creating a higher degree in the subject. He pointed out that it seemed "natural that it should take an initiative in a course that will be followed by other universities." Two days later the board requested that the medical professors should present their proposal in more detail, and so Stokes and his colleagues came to draw up the first curriculum in state medicine. The next year this was submitted in detail to the GMC itself and accepted as a model. It was grouped under seven headings-and may be described as compendious. 
The full detail runs to five pages of small print in the university calendar. ${ }^{2}$ On the recommendation of the board the university agreed to offer a certificate in state medicine but confined eligibility to its own graduates; quite deliberately no courses or instruction were proffered. Paget at Cambridge had simply proposed a test of fitness to practise and Stokes was of the same mind. The yearly number of medical graduates in Dublin at that time was about 20 , so that even if $10 \%$ wanted to do the examination the numbers taking it would be small. Candidacy was therefore opened to graduates at Oxford and Cambridge shortly afterwards. Eighteen months

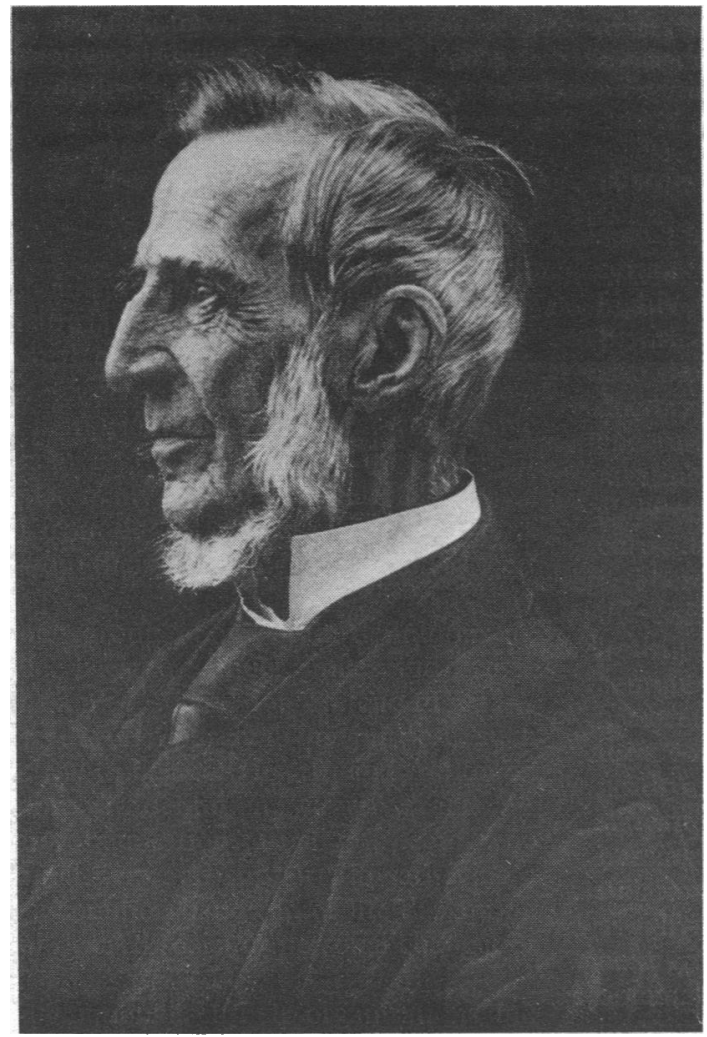

FIG 4-Sir George Paget (1809-92), son of a Yarmouth merchant, whose younger brother, James, also a member of the GMC, described osteitis deformans, a form of mammary carcinoma, and other conditions.

after Paget had sent his letter to Stokes in the Trinity term of 1871 four candidates in the examination hall of Trinity College Dublin successfully sat the first examination to be held anywhere in state medicine; one of them, Gerald Francis Yeo, subsequently became professor of physiology in King's College London, two were honorary physicians to the Meath Hospital with fashionable Dublin practices, and the fourth was a general practitioner in Bedford. Hence none of them followed the career for which the examination had been devised to qualify them.

The candidates wrote nine papers, one on each of the seven subjects set out by Stokes's professorial committee, together with one on hygiene as a separate subject from medical jurisprudence and one set by the regius professor of physic himself; it contained 15 questions, which were mostly epidemiological or concerned with public health philosophy. ${ }^{2}$ The examination was a searching one and, though we have no way of judging the standard, we must assume that $\mathrm{Dr}$ Yeo and his colleagues were well informed men.

\section{Edinburgh}

Edinburgh acted independently. Partly because of this, partly because it reached a different solution to the problem, ${ }^{2}$ and partly because of space I make no attempt to recount events there in any detail, except to say that on 23 October 1874 four candidates in Edinburgh were successful at the first examination for the BSc in public health. More detail is given in a companion paper. ${ }^{2}$ The examination came under the aegis of the faculty of science. Prime movers in the university had been Christison (fig 5) together with Sir Douglas Maclagan, both of whom held the chair in medical police in the medical faculty and in medical jurisprudence in the law faculty, but the member of parliament for the university, Sir Lyon Playfair, had provided the initial impetus. This degree was open to anyone whose name appeared on the medical register. The influence of the science faculty is clear. The syllabus was very different from the one which Stokes had developed in Dublin and which had been formally accepted by the GMC.

\section{Certificate from Cambridge for all registered "medical men"}

In December 1874, two months after the Edinburgh BSc had been introduced, Paget moved for the third time in Cambridge. Through the vice chancellor he drew the attention of the senate to the fact that the Universities of Dublin and Edinburgh already had established degrees (sic) in state medicine or public health. The Board of Medicine proposed that the university should establish examinations and grant certificates of competency in the parts of state medicine relevant to the work of "officers of health." It went on to "recommend that the examinations should not be confined to members of the university alone." Subjects should be physics and chemistry; laws relating to public health; sanitary statistics; and the origin, propagation, pathology, and prevention of epidemic and infectious

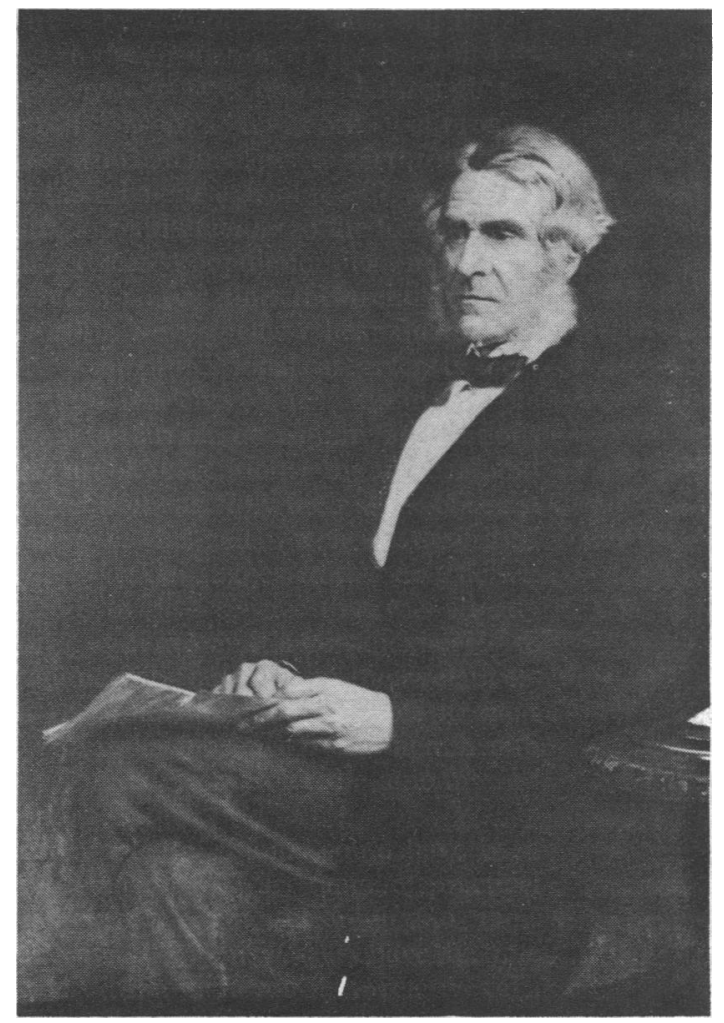

FIG 5-Sir Robert Christison (1797-1882), who was one of a series of distinguished men to hold the chair in medical jurisprudence in Edinburgh university, the tenants of which developed early teaching of public health there. He acceded to it at the age of 25 and shortly afterwards was chief witness for the Crown in the case of the body snatchers Burke and Hare. As Stokes was the Queen's nominee for Ireland, so was Christison her nominee for Scotland. As dean of the faculty of medicine in Edinburgh and member of the university court he, along with Sir Douglas Maclagan, played an important part in creating the new degrees in public health. Credit for the establishment of the British Pharmacopoeia goes in large part to him and Sir Henry Acland. (Courtesy of the librarian of the Royal College of Physicians of Edinburgh.)

diseases-a curriculum noticeably different from that of the MD six years previously.

The three universities-Cambridge, Dublin, and Oxford-then recognised (and still recognise) each other's degrees on a reciprocal basis, but not on any basis did they recognise those of any other. It was therefore hardly surprising that the Board of Medicine's recommendations should stimulate public discussion in the senate. The vice-chancellor reminded the university that since 1870 Cambridge medical graduates had been able to take the MD in state medicine; he went on to argue that therefore the new certificate 
should not be so restricted. On this basis Paget and his colleagues won the day without modifying their proposals. The open examination was probably the biggest single factor underlying the general success of the Cambridge contribution to education in the subject over 40 or 50 years. On 5 October 1875 the first examinations were held, called-perhaps cussedly, perhaps cleverly-public health examinations. In addition to writing four papers, candidates were required to do a laboratory practical in chemistry and physics and a practical in fieldwork, which included preparing a sanitary report. A heavy bias towards chemistry, in particular, and physics was to characterise the Cambridge examination for a quarter of a century. Throughout that time Liveing, professor of chemistry and a pioneer in the spectroscopy of the planets, was the central figure in the syndicate responsible for the examination. Appointed to his professorship in 1866 he was still on the syndicate in 1896 when it had finally conformed to the wishes of the GMC. No doubt it was through Liveing's influence that in the second year, 1877, the name was changed to an "Examination in Sanitary Science leading to the Certificate in State Medicine." We shall return to Oxford and the problems Acland was facing there.

\section{Acland's progress with the GMC and the privy council}

In the mean time several other consequences of the Irish meeting of the BMA in 1867 deserve mention. Acland followed Stokes as president of the association. We have already seen that as chairman of the BMA state medicine committee he wrote a letter to the GMC leading to the establishment of a state medicine committee in the council. This committee was to conduct what seems to have been the first public consultation ever made by the council. It took the form of posing in writing eight questions to 25 distinguished Britons from many walks of life (described in the minutes as "English correspondents"): for instance, the Lord Chief Justice; William Farr, the lord president of the council; the Bishop of Limerick; and John Simon. Rokitansky, Pettenkofer, and 10 other distinguished foreigners were also approached. All were asked for their views about, for example, the structure of a curriculum in state medicine; the timing and nature of instruction; and, finally, "How should a Court of Examiners be constructed?" (Acland was to fight long and hard for a national examining board in state medicine-presumably because of opposition by the University of Oxford to the examination for his Certificate of Preventive Medicine and Public Health-only to be foiled by the Royal College of Surgeons of Ireland.) As might be expected, the answers to all the questions were as various as the people whose advice was sought. Maclagan, who played a leading part in establishing the BSc in Edinburgh, went so far as to say that he could not approve of a diploma because "by the creation of a separate class of graduates in state medicine these will be seriously compromised." This notwithstanding, he provided very constructive answers to the committee's questions.

The committee concluded that a qualification in state medicine should be made a formal responsibility of the GMC in the next medical Act and that those who wished to devote themselves to this branch of the public service should obtain a diploma "certifying the possession of knowledge adequate to the end in view." By virtue of the heterogeneity of the consultants, not surprisingly the committee was unable to draw conclusions about a curriculum. A long, personal commentary by Rumsey was included as an appendix to the report; he set out tasks for a state physician but had nothing at all to say about the curriculum. We have seen how Stokes used the job description in Rumsey's appendix as a template and how, despite the approval of the GMC, each university went its own way.

Another action of Acland when he was president elect of the BMA and chairman of its committee on state medicine was perhaps the most important of all. On 22 May 1868 (the month that Paget's MD was proposed in Cambridge) he led a combined group drawn from the BMA and the Social Science Association (including Edwin Chadwick himself) in a delegation which waited upon the Duke of Marlborough, at that time lord president of the privy council. They petitioned for the establishment of a royal commission to inquire into the whole matter of state medicine and its promotion.

\section{Royal Sanitary Commission}

The petition was successful and the Royal Commission on Public Health, subsequently known as the Royal Sanitary Commission, was formed in late November 1868 by Disraeli, with Acland, Stokes, and Rumsey among its members as well as Farr and Simon. Because of the change of government, however, it did not start work until late next spring, when Rumsey had been dropped from membership (though he did give verbal evidence). The following year he was no longer a member of the GMC. We may conclude that these were not happy events for him and that Gladstone's privy council would not accept his grandiose and rather imprecise views of what should be done under the heading of state medicine. Nevertheless, he remained active in pressing for a qualification in state medicine through the BMA and was elected FRS-Do we sense the hand of Acland here? The commission worked very quickly and as an immediate result of its recommendations public health Acts were passed in 1872 and 1875, and in 1874 Farr's Registration of Births and Deaths Act-much of which stands today, but which represented a dismemberment of Rumsey's monolithic conceptjoined them on the Statute Book. So far as the matter which stimulated its formation was concerned-namely, the need for acceptably high standards in the training of practitioners of state medicine-things did not proceed so well. It was not until 1886 that a medical Act which gave the GMC the authority to control standards and content of education in public health was eventually passed, and even then the law was faulty. In 1888 the local government act clarifying the relationships between the medical officer of health and his employers became law.

\section{Acland and intransigence in Oxford}

Acland faced opposition and frustration in his attempts to establish an examination for a certificate in Oxford. Whereas the other three universities recognised their certificates or degrees as formal university qualifications and published officially the names of men who received them, this was not the case in Oxford. Instead the registrar was instructed to keep a record of certificands in preventive medicine and public health in a special book that he was required to provide and each entry had to be certified by the signature of the examiners. As in Dublin in the early years, candidacy was confined to medical graduates of Oxford University's own tiny school. The examination in public health and preventive medicine there was first advertised in May 1876, when Rolleston, Farr, and Simon were among the appointed examiners; the syllabus consisted of hygiene, sanitary law, sanitary engineering and apparatus, and vital statistics. There were no takers. In December 1877, however, George Blundell Longstaff, MA, MD, of New College, wrote satisfactory answers to questions in five papers (two in hygiene and one in each of the other subjects) and also took a practical examination in sanitary engineering. His name may not have been published in the Oxford University Gazette but his certificate (fig 6) was signed by Farr

\section{$\boldsymbol{W}$ the undersigned Examiners in the University}

$$
\begin{aligned}
& \text { of Oxford hereby certify that we have duly examined } \\
& \text { Bachelor of Medicine, in subjects bearing upon Preventive }
\end{aligned}
$$

Medicine and Public Health, according to the Statute made by the University in that behalf, and that he has shein a competent knorled ge of the same.

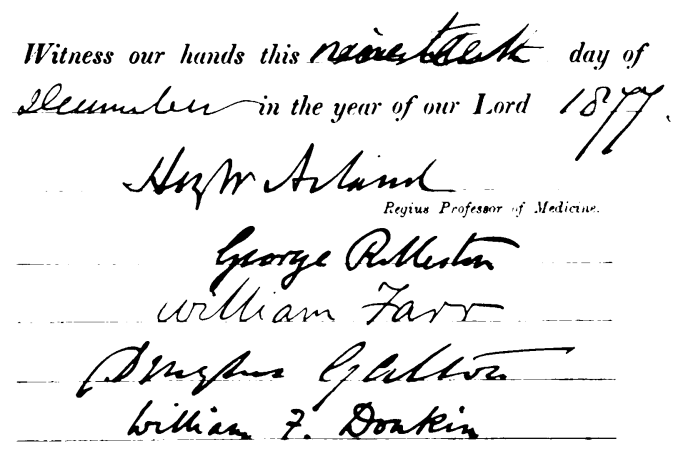

FIG 6-First certificate of preventive medicine and public health to be awarded in Oxford. William Farr's signature appears; in addition, Sir John Simon accepted the appointment of examiner but was unable to serve. (Courtesy of Bodley's librarian, University of Oxford. 
and Acland among others (Simon withdrew from the board of examiners without ever having had an opportunity to serve). We may speculate whether any other candidate for a professional qualification anywhere was exposed to the challenge of Farr's penetrating mind. The odds were so heavily weighted against Acland by his unsympathetic university that he saw only three candidates acquire his certificate of preventive medicine, which, despite persistent advertising, attracted no interest from the tiny group eligible to take it; as a result it was suspended between 1888 and 1896, when a new examination for the Diploma in Public Health was successfully introduced. Nevertheless, his efforts did yield a first; whereas Dublin and Cambridge simply looked on themselves as examining bodies for the first 10 years or so Edinburgh relied heavily on freelance extramural instruction for its students, as early as January 1870 - that is, 18 months before the first examination in Dublin-Charles C Pode, MB, of Exeter College, gave a regular course in pathology and state medicine, which from 1873 was advertised daily in the university's gazette. This ran for several years, until Poole's premature death from tuberculosis; evidently the course was run at Acland's personal expense (H L Harley, personal communication). All of the papers compiled by the Oxford examining board under the chairmanship of Acland showed a vivacity and variety which was not evident in other centres.

\section{Poorly written legislation and delays in control of standards}

The last legislation to ensue from the report of the Royal Sanitary Commission was the (third) Medical Act 1886. This gave the GMC authority to inspect qualifying examinations in order to satisfy itself of their "sufficiency" and in a short clause required that diplomas in public health should be entered in the register. In this clause the council was also charged with the statutory responsibility for seeing that "courses of study ensure the standard of proficiency which the council considered necessary." But only qualifying examinations were open to inspection, and this was not a qualifying examination; the legislators had failed explicitly to recognise that without inspections of the postgraduate diploma in Public Health the GMC had no means of enforcing the law. As a result eight more years were to elapse before a legally acceptable solution was found and Duffey was appointed inspector.

On 1 June 1889, after a great deal of internal wrangling, the GMC, with Acland still in the president's chair and Sir John Simon providing the vis a tergo, described precisely what it expected of the bodies examining aspirants for the post of medical officer of health. It ruled that no diploma in public health should be accepted as deserving of recognition by the council unless one year had elapsed between obtaining a registrable qualification in medicine, surgery, and midwifery and the examination in sanitary science, public health, or state medicine, and also that during that year each candidate must have attended a six month course of instruction in a laboratory approved by the body granting the qualification. Every candidate must also produce evidence of having completed six months' practical "outdoor sanitary work" under a medical officer of health responsible for a substantial population; examiners must be specially qualified; and the examination must comprise laboratory work as well as written and oral examinations. Exemptions to the rules based on candidates' age and experience were set out. Six weeks later, on 18 July 1889, Acland resigned his presidency of the GMC. Perhaps he would have stayed on and hurried things up had he realised that a further six years were to slip by before the inspections were enforced which alone could enable the council to satisfy itself that "conditions of education and examination ... ensure the possession of a distinctively high proficiency, scientific and practical, in all branches of study which concern the public health." None of the universities which supported him at the outset had supported the introduction of the rules set out above. In the education committee Haughton, of Dublin, and Humphrey, of Cambridge, had voted against them, and Sir William Turner, of Edinburgh, who was later to succeed Acland as president, abstained.

\section{Discipline finally established}

One of the remarkable aspects of the examination in three of the four centres where enough candidates were forthcoming for a judgment to be made was stasis in the intellectual content of what was to be studied. True there were changes, but they were infrequent and (with the exception of Edinburgh, which introduced bacteriology in 1888) of limited consequence. Cambridge examined more candidates than the other three universities combined but, as we have seen, there was a heavy emphasis towards chemistry, which increased during the early years. The GMC provided the vehicle for change in the nuts and bolts of the curriculum. I wonder, however, how much more rapidly a proper appreciation not only of bacteriology but of the real breadth of public health would have developed had Acland worked in a less unsympathetic place than Oxford. He did not resign his regius professorship until the autumn of 1895 , when the future was assured and the decision taken to offer a qualification to all. In 1896, when he finally saw the examination reinstated there as a Diploma in Public Health, open to all comers, there were four papers, one of which was on pathology and bacteriology, and all of its six questions included a bacteriological component. By then Rumsey, Stokes, Christison, and Paget (knighted late in life) were all dead and he was failing in health.

\section{Conclusion}

It seems clear now that right from the outset Henry Acland had been the central figure in the battle for the establishment of academic public health which was waged over nearly 40 years. Certainly from 1858, when the GMC first sat, he chaired the key committees, led the delegations, and so on through the introduction of the new laws in the early 1870s, the frustrations of the 1880 s, when he was president of the GMC, to final success just before the turn of the century. This, one of his many contributions to medicine and science, seems to have been overlooked by biographers and historians, though arguably it was the most important thing he did.

Duffey was the epilogue to this phase of the story. He was a physician with an honorary appointment in two of the Dublin teaching hospitals and president of the Royal College of Physicians of Ireland. In recognition of his services in inspecting for the GMC qualifying examinations as well as those for the Diploma in Public Health he was knighted in 1896 . He played a most influential part in helping schools to create a rational and practical curriculum which applied the latest scientific thought. His sharp eye, wit, and elegant style make his reports a pleasure to read. Of his own school, Dublin, Duffey wrote, "Both the candidates who presented themselves being rejected, it may be concluded ... that the qualification ... is only conferred on those who show proficiency...." A popperian argument?

This paper was presented at an annual meeting on the history of medicine at the Wellcome Trust, 26 June 1985.

Sources include the university archives of the Bodleian Library, Oxford, the library of Trinity College Dublin, the university libraries at Cambridge and Edinburgh, and the libraries of the Royal Society of Medicine and the Wellcome Institute. I am grateful for the willing guidance of the staff of all these institutions. Other sources are the minutes of the GMC and journals, principally the BMF, Lancet, and The Times.

\section{References}

1 Rumsey HW. Essays in state medicine. London: Churchill, 1856.

2 Acheson RM. The origins, content, and early development of the curriculum in state medicine and public health 1856-1895. (To be published.)

\section{Pheasant pluckers' wrist}

I should like to draw attention to the condition pheasant pluckers' wrist, which is comonly seen in rural orthopaedic practice at this time of the year. All the signs of inflammation are present on examination of the wrist and extensor tendons, suggesting early rheumatoid arthritis. As expected, the condition becomes increasingly troublesome towards Christmas and resolves in the new year. It is unusual for patients to associate the plucking of birds with the distressing symptoms, and they may have complained of the symptoms and been subjected to various blood investigations over several years before the diagnosis is made.-C PETER BROAD, consultant orthopaedic surgeon, Christchurch. 